\title{
Effect of Soaking/Fermentation Periods on the Phytic Acid Polyhenolic Content and Invitroprotein Digestibility of "Akara" and "Moin-Moin" Prepared from Cowpea/Maize Flour Bend
}

\author{
Akusu, O.M. and Wordu, G.O \\ Department of Food Science and Technology, Rivers State University of Science and Technology, \\ Nkpolu - Port Harcourt. \\ wordugab@yahoo.com
}

\begin{abstract}
The effect of soaking periods on the invitroprotein digestibility of "akara" and "moin-nioin" prepared from cowpea/maize flour blend was investigated. "Akara and mom-mom" were prepared from a blend of cowpea/maize flour in which the cowpea and maize seeds were socked for 0, 4, 8, 12 and 16 hours, processed into flour, blended into a ratio of 70:30 and used for akara and mom-mom preparation. The akara and mommom prepared from each socking period was analysed for poiyphenols, phytic acid content and invitro protein digestibility. The result showed that there was a significant $(p<0.05)$ increase in the invitroprotein digestibility of akara and mom-mom as the soaking periods of the cowpea/maize increased from zero hr to $16 \mathrm{hr}$ whereas a significant decrease (p0.05) was observed in the polyphenolic and phytic acid content of "akara" and mommom. Therefore soaking of cowpea and maize in "akara" and "moin-moin" preparation improves their nutritional values.
\end{abstract}

Keywords: Invitroprotein protein digestibility, akara, mom-mom, soaking periods, cowpea and maize.

\section{INTRODUCTION}

"Akara" and "Moin-moin" has been described as the most popular cowpea-based food product in West Africa, which makes their contribution to the diet particularly important.

Several attempts has been made to improve on the protein quality of "akara" and "main-main" by substituting up to $30 \%$ of cowpea with maize in their preparation (Giami et al 2003, Akpakpunam 1985, Akusu and Kiin-kabari 2012). Cowpea play a critical role in the lives of millions of people in African and other parts of developing world where it is a major source of dietary protein that nutritionally complement cereals and tubers of low protein levels.

The use of legumes and cereals in human nutrition is inhibited by the presence of anti-nutritional factors which chelate the vital nutrients in them thereby making them unavailable to the body.

Many legumes including cowpea contains tannins and trypsin inhibitors which decreases protein digestibility (Gate house and Boulter, 1983). Maize seeds contain phytates which reduces the bioavailability of some vital minerals.

Anti-nutritional factors have been defined as those toxic compounds which have a negative effect on the bioavailability of nutrients (Von Egmond and Speyers, 1990). Plant foods have been reported to contain a large number of naturally occurring toxic compounds that adverse effect on man and animal when ingested.

Anti-nutritional factors in any food, gained importance as they decide its nutritional value in terms of biological availability including the food digestibility and nutrient absorption from the intestinal tract. It has been reported that tannis adversely affect the nutritive value of legumes by reducing the proteolytic digestibility of proteins where as phytic acid reduceses the bioavailability of some essential minerals (Vanderpoel, 1990).

Akingele and Akinylosotte (1991) reported increase in the protein content of cowpea after soaking the seed. Fermentation has been reported to improve the nutritional value of food legumes and cereals by decreasing the levels of anti-nutrients and improve protein digestibility (Eka, 1980). 
Protein quality measurements are used to predict the nutritional quality of food proteins. All proteins are digested, absorbed and utilized to different extents. The difference in protein digestibility arises from susceptibility of proteins to enzymic hydrolysis in the digestive system. Protein digestibility is a measure of the proportion of food protein that is absorted after digestion.

The improvement in in-vitro protein digestibility of oil seed, legumes and cereals by soaking, germination, fermentation and cooking had been reported bt Giami 1993, Giami et al (2002), Achinewhu 1983 \& 1986. Giami (2004) reported that fermentation decrease polyphenol and phytic acid content of fluted pumpkin.

Digestibility is the most important determinant of the quality of a protein. The amount of each amino acid that is absorbed determines protein utilization in the body. The digestibility of proteins can be assessed by the in-vitro method. Zamara \& Fields (1979) reported that the nutritive quality of cowpea was markedly improved as a result of fermentation.

Taylor and Taylor (2002) reported improvement in protein digestibility brought about by fermentation which appears to be that during soaking and fermentation, the insoluble proteins (prolamine and ghitelin) undergo structural changes which make them more accessible to Pepsin attack.

In Nigeria, the recent traditional method of "akara" and "moin-moin" preparation involves the preparation of cowpea paste from cracked, winnowed cowpea without prolong soaking. The cowpea is cracked, winnowed and soaked for just 5 minutes, dehalled, washed and ready for grinding into paste for akara and moin-moin preparation. This method is likely to reduce the digestibility of "akara" and "moin-moin" prepared from such legumes \& cereal. Thus increasing the soaking period of the cowpea/maize can go a long way to improve the digestibility of "akara" and "moin-moin" prepared from such cowpea/maize by decreasing the anti-nutrient factors. This study was aimed at investigating the effect of soaking periods on the phytic acid tannin citent and in-vitroprotein digestibility of "akara" and "moin-moin" prepared from such cowpea/maize flour blend.

\section{MATERials AND Methods}

\subsection{Materials}

"Bkickeye" variety of cowpea (Viqna unglliculate L. Walp), white maize (Zea mays), vegetable oil and other ingredients used in this study were purchased from a local market in Port Harcourt, Nigeria. All chemicals used for this study were of analytical grade. Pepsin and Pancreatic enzymes were obtained from Sigma Chemical Co. (St Louis, MO, U.S.A).

\subsection{Preparation of Cowpea and Maize Flour Samples}

The procedure described by Odum et al (1981) was used for the preparation of the cowpea and maize flour. Whole seed samples $(5 \mathrm{~kg})$ each of cowpea and maize grains were soaked at room temperature $\left(28 \pm^{\circ} \mathrm{C}\right)$ in tap water at a bean to water ratio of 1:5 for $0,4,8,12$ and 16 hours. The soaked cowpea was manually dehaulled and the maize grains were separately autoclaved at $121^{\circ} \mathrm{C}$ for $15 \mathrm{~mm}$, oven dried at $60^{\circ} \mathrm{C}$ for $24 \mathrm{hr}$ in a hot air oven (model QUB 3050/OG, Gallenkamp, U.K), ground using a laboratory mill (Numex pep grinding mill, India and screened through a $0.25 \mathrm{~mm}$ British Standard Sieve (model BS 410, Endecotts, Limited, U.K) to obtain cowpea and maize samples (Fig 1). The cowpea flour and maize flour were bended at a ratio of 70:30 for each soaked periods.

\subsection{Preparation of "Akara"}

A modified recipe (Table 1) of Mc Watters (1983) and the procedure outlined by Ngoddy et al (1986) and Giami et al (2003) were used for akara preparation. Five hundred gram of each blended sample were mixed with $400 \mathrm{ml}$ of warm water $\left(50^{\circ} \mathrm{C}\right)$ in a mixing bowl using a Philip electric blender (model NR 2817/A, Mexico); salt, ground onion and tcitashe red pepper and blended for $2 \mathrm{~mm}$ to form a smooth paste. The paste was allowed to stand for $3 \mathrm{~min}$, then further whipped for $5 \mathrm{~min}$ in a kenwood blender (Model A $907 \mathrm{D}$ ) at a speed $5000 \mathrm{rpm}$ to incorporate air.

Twenty $(2 \mathrm{O} \pm \mathrm{lg})$ of the whipped paste was spooned into 1 liter of hot cooking refined vegetable oil (King's Brand, Devon Ind. Singapore) for frying at $190^{\circ} \mathrm{C}$ for $5 \mathrm{~min}$ to yield akara balls. The fried akara balls were drained on absorbent pepper, cooled and was oven dried at $50^{\circ} \mathrm{C}$ for $12 \mathrm{hrs}$ arid was used for the determination of phytic acid, tannin content and invitroprotein digestibility. 
Effect of Soaking/Fermentation Periods on the Phytic Acid Polyhenolic Content and Invitroprotein Digestibility of "Akara" and "Moin-Moin" Prepared from Cowpea/Maize Flour Bend

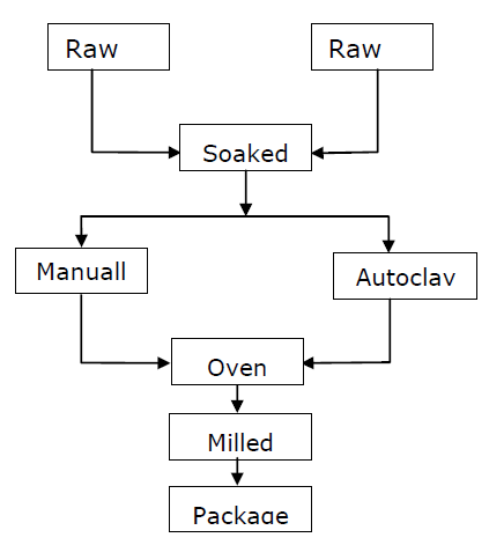

Figure1: Production of Cowpea Flour and Maize Flour Source: Odum et al (1981)

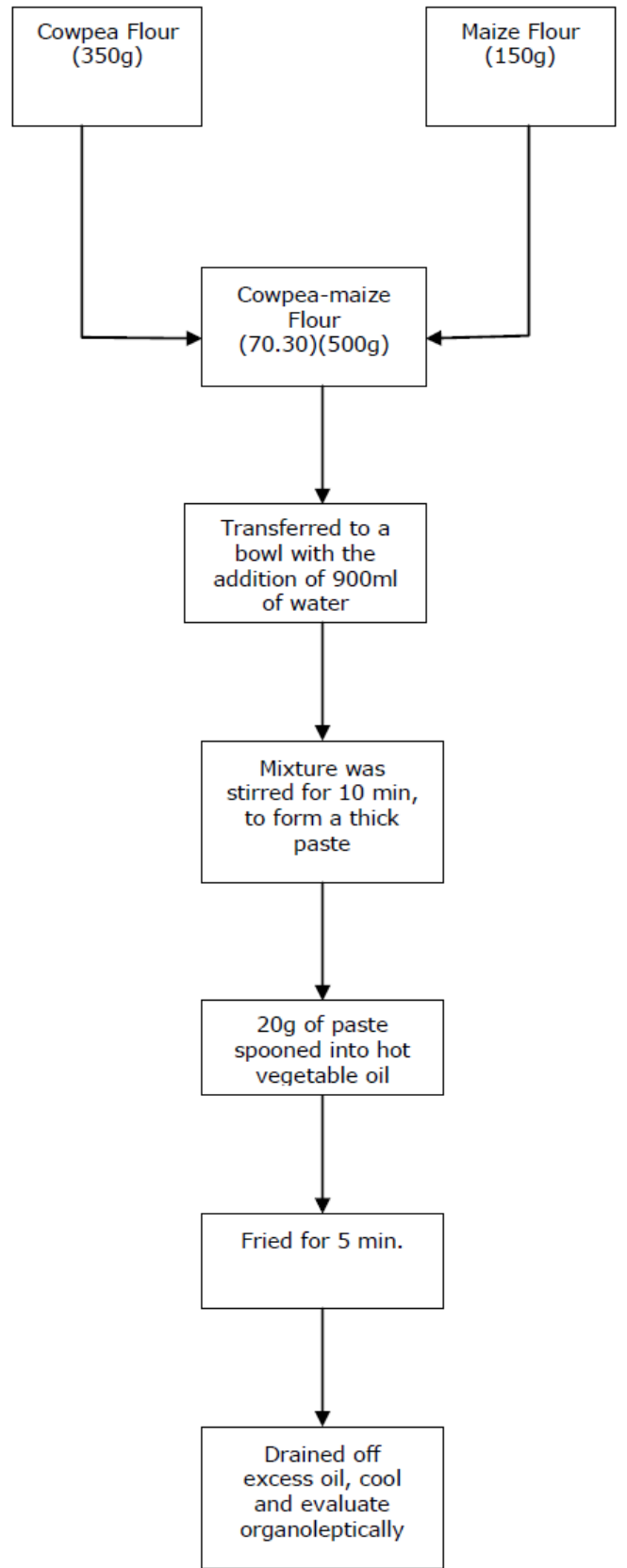

Figure2: Preparation of "Moin-moin" from cowpea-maize flour blends

Source: Ngoddy, 1986, Akusu and kiin-Kabari, 2012. 
Table1. Ingredients for akara preparation

\begin{tabular}{|l|l|}
\hline \multicolumn{1}{|c|}{ Ingredients } & \multicolumn{1}{c|}{ Amount } \\
\hline Cowpea/maize flour blend & $500(\mathrm{~g})$ \\
\hline Tatashe red pepper (ground) & $60(\mathrm{~g})$ \\
\hline Onions (ground) & $60(\mathrm{~g})$ \\
\hline Salt & $10(\mathrm{~g})$ \\
\hline Water & $400 \mathrm{ml}$ \\
\hline
\end{tabular}

\subsection{Preparation of "Mom-Mom"}

The recipe of Akusu and Kiin-Kabari (2012) with slight modification. The procedure outlined by Akusu and Kiin-Kabari (2012) was used for moin-moin preparation with slight modification. Five hundred $(500 \pm 1 \mathrm{~g})$ of each set of the soaked cowpea; maize (70:30) flour blend were mixed with all ingredients as shown in table 2. in a mixing bowl.

Table2. Ingredients for Moin-moin preparation

\begin{tabular}{|l|l|}
\hline \multicolumn{1}{|c|}{ Ingredients } & \multicolumn{1}{c|}{ Quantity } \\
\hline Cowpea/maize flour & $500(\mathrm{~g})$ \\
\hline Fresh pepper & $60(\mathrm{~g})$ \\
\hline Onion & $60(\mathrm{~g})$ \\
\hline Tatashe red pepper or shumgbo pepper & $40(\mathrm{~g})$ \\
\hline Cray fish & $50(\mathrm{~g})$ \\
\hline Magi cube & $20(\mathrm{~g})$ \\
\hline Delice spice & $10(\mathrm{~g})$ \\
\hline Onga spice & $10(\mathrm{~g})$ \\
\hline Salt & $10(\mathrm{~g})$ \\
\hline Vegetable oil & $180(\mathrm{ml})$ \\
\hline Hot water $\left(90^{0=\mathrm{C})}\right.$ & $900(\mathrm{ml})$ \\
\hline
\end{tabular}

One hundred and eighty $(180 \mathrm{ml})$ of vegetable oil was then added to the mixing bowl, a wooden spatula was used to mix the cowpea/maize flour blend and all the ingredients to form a smooth paste. The paste was allowed to stand for $3 \mathrm{~min}$ and $900 \mathrm{ml}$ of hot water $\left(90^{\circ} \mathrm{C}\right)$ was then added to the smooth paste, and mixed thoroughly.

Three hundred $(300 \mathrm{ml})$ of the smooth paste was each dispensed into aluminum foil, packaged and steamed for $1 \mathrm{hr}$. The product was then cooked and evaluated organoleptically for all the batches soaked for $0,4,8,12$ and $16 \mathrm{hr}$.

Polyphenol are phenolic compounds occur naturally in plant tissues. tannins are a kind of polyphenol characterized by high molecular weight (500-3000). Containing sufficiently large number of phenolic groups (polyhydric phenols). Polyphenols have been reported to lead to reduction of growth in animals by formation of complexes with proteins and inbihition of digestive enzymes (Liener, 1980).

\subsection{Polyhenols Determination}

Polyphenols were determined using the vanilla $-\mathrm{H}_{2} \mathrm{SO}_{4}$ assay described by Wilson and Blunden (1983) with reference to a standard graph based on phloro-glucinol. The results are expressed as $\mathrm{Mg}$ phloroglucinol equivalents per $100 \mathrm{~g}$ dry akara or moin-moin weight.

\subsection{Phytic Acid Determination}

A combination of two methods was used for the phyic acid determination using $1 \pm 0.0 \mathrm{lg}$ of akara and moin-moin samples. The extraction and precipitation of phytic acid were done according to the method of Wheeler and Ferrel (1971); Iron in the precipitate was measured by procedure 14.013 of the AOAC (2006)A 4:6 Fe/p molecular ratio was used to calculate phytic acid content as expressed as mg phytic acid per $100 \mathrm{~g}$ of akara or moin-moin.

In-vitroprotein digestibility of akara or moin-moin samples was determined by the procedure outlined by Sanders et al as modified by Monsor and Yusuf (2002) to assess protein digestibility (in-vitro) of akara and moin-moin using double enzyme porcine Pepsin powder (P700) and Pancreatin (1500) obtained from sigma chemical Co. (St Louis, MO, USA). The nitrogen content of the samples and of the undigestibility residue were determined by Kjeldah method (AOAC 2006). Protein digestibility was calculated using the following equation.

Protein digestibility $(5)=\frac{\text { digestible protein }}{\text { Total protein }} \times \frac{100}{1}$ 
Effect of Soaking/Fermentation Periods on the Phytic Acid Polyhenolic Content and Invitroprotein Digestibility of "Akara" and "Moin-Moin" Prepared from Cowpea/Maize Flour Bend

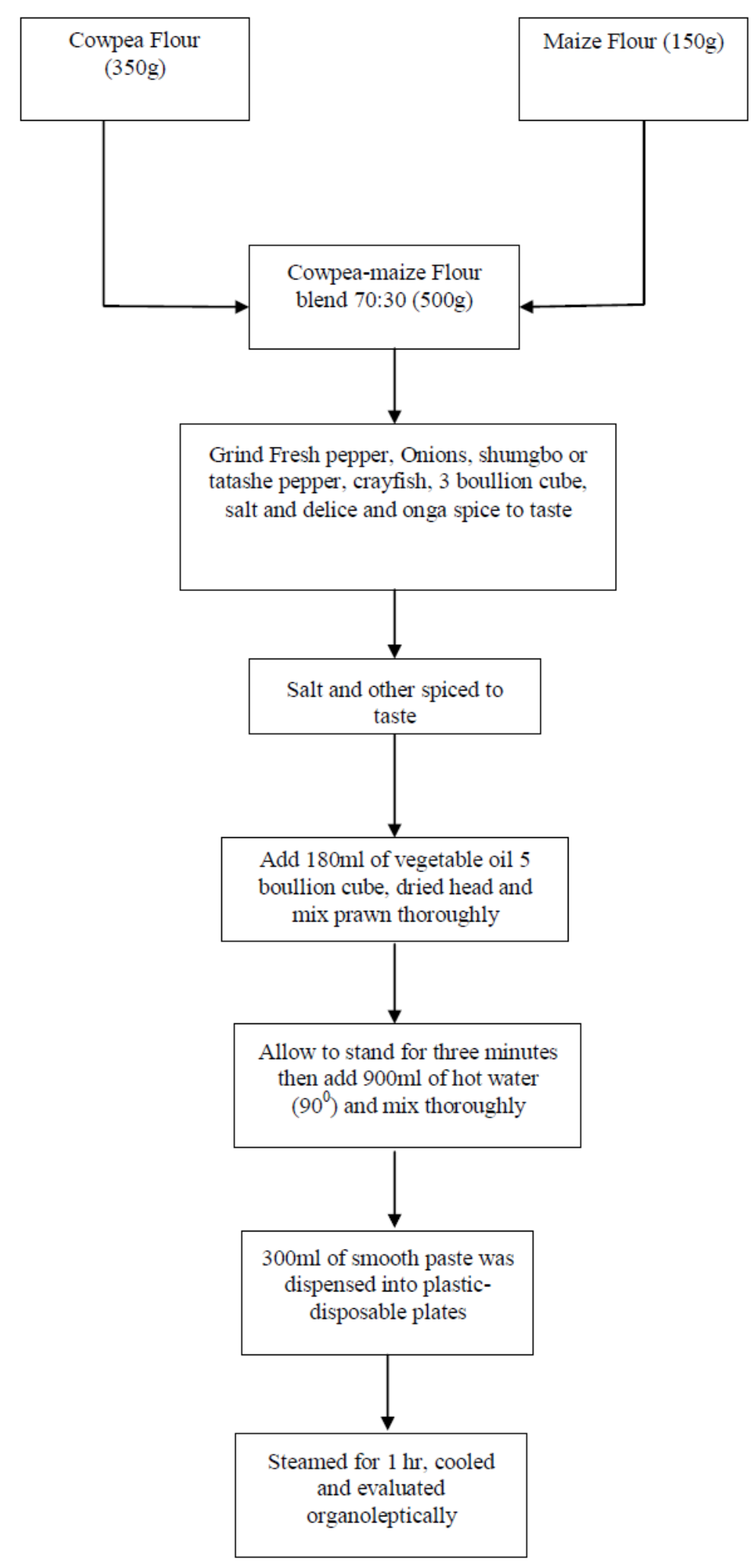

Figure3. Preparation of "akara" from cowpea-maize flour blends

Source: McWatters (1983). Noddy 1986, Giami et al 2003

\section{RESULT AND DISCUSSION}

Table 3 shows the effect of soaking periods on the invitroprotein digestibility, phytic acid content and polyphenols of "akara" prepared from cowpea/maize flour blends. There was a significant $(p<0.05)$ decrease in the level of polyphenols and phytic acid content as the soaking period increased from zero $\mathrm{hr}$ to $1616 \mathrm{hrs}$ whereas a significant $(\mathrm{p}<\mathrm{O} . \mathrm{O} 5)$ increase was observed in the invitroprotein digestibility of the "akara" prepared from the cowpea/maize flour blend. 
Table3. Effect of Soaking Periods on the Phytate Polyhenols and in Vitro Protein Digestiability of "Akara", Prepared from Cowpea/Maize Flour Blend.

\begin{tabular}{|l|l|l|l|}
\hline Socking Period (Hr) & Invitroprotein Digestiability \% & Polyphenol (Mg/100g) & Phytic Acid (Mg/100g) \\
\hline 0 & $39.69^{\mathrm{a}}$ & $0.57^{\mathrm{a}}$ & $0.34^{\mathrm{a}}$ \\
\hline 4 & $41.98^{\mathrm{d}}$ & $0.48^{\mathrm{b}}$ & $0.31^{\mathrm{a}}$ \\
\hline 8 & $56.88^{\mathrm{c}}$ & $0.34^{\mathrm{c}}$ & $0.25^{\mathrm{b}}$ \\
\hline 12 & $66.73^{\mathrm{b}}$ & $0.30^{\mathrm{c}}$ & $0.20^{\mathrm{b}}$ \\
\hline 16 & $74.67^{\mathrm{a}}$ & $0.21^{\mathrm{d}}$ & $0.16^{\mathrm{c}}$ \\
\hline
\end{tabular}

The effect of soaking periods on the in vitroprotein digestibility, phyphenols and phytic acid content of "moin-moin" prepared from cowpea/maize flour blend is presented in table 4 . The invitroprotein digestibility of moin-moin increased from $39.38 \%$ at zero he to $75.29 \%$ after 16 hrs of soaking while the polyhenols and phytic acid decreased significantly $(\mathrm{p}<0.05)$.

Table4. Effect of Socking Periods on the Phytate, Polyhenols and in Vitro Protein Disgestability of "Moin Moin” Prepared From Cowpea/Maize Flour Blend.

\begin{tabular}{|l|l|l|l|}
\hline Socking Period (Hr) & Invitroprotein Digestiability \% & Polyphenol (Mg/100g) & Phytic Acid (Mg/100g) \\
\hline 0 & $39.38^{\mathrm{c}}$ & $0.58^{\mathrm{a}}$ & $0.32^{\mathrm{a}}$ \\
\hline 4 & $40.58^{\mathrm{d}}$ & $0.47^{\mathrm{b}}$ & $0.31^{\mathrm{a}}$ \\
\hline 8 & $55.98^{\mathrm{c}}$ & $0.35^{\mathrm{c}}$ & $0.25^{\mathrm{b}}$ \\
\hline 12 & $65.23^{\mathrm{b}}$ & $0.28^{\mathrm{c}}$ & $0.18^{\mathrm{c}}$ \\
\hline 16 & $75.29^{\mathrm{a}}$ & $0.14^{\mathrm{e}}$ & $0.12^{\mathrm{c}}$ \\
\hline
\end{tabular}

\subsection{Polyphenols are Phenolic Compounds Occurring Naturally in Plant Tissues}

The result shown in tables 3 and 4 reveal that the polyphenolic and phytic acid content of both akara and moin-moin decreases as the soaking periods increases from zero hr to $16 \mathrm{hrs}$, there is a significant $(\mathrm{P}<0.05)$ decrease in the polyphenolic and phytic acid content of akara and moin-moin while the invitroprotein digestibility of akara and moin-moin increased significantly.

Polyphenols have been reported decrease in growth rate of animals by formation of complexes with proteins and inhibition of digestive enzyme (Liener, 1980). Digestibility is the most important determinant of the quality of a protein. The amount of each amino acid that is absorted determines protein utilization in the body. The digestibility of proteins can be assessed by the in-vitro method.

The improvement in in-vitro protein digestibility of oil seeds, legumes and cereals by soaking germination, fermentation and cooking had been reported by Giami 1993, Giami et al 2002, Achineqhu 1983 and 1986. Sandberg and Andlid, 2002 reported a significant decreased in polyphenols and phytic acid during soaking and fermentation of legumes, they suggested that the loss of phytic acid during fermentation might be due to the action of fermentating microorganism which hydrolyze phytate into inositol and orthophosphate.

Barber et al, 1989 isolated various bacteria genera such as Bacillus and Pseudomanas from fermenting fluted pumpkin seeds, they stated that phytate-degrading enzyes were detected in such general of bacteria.

Giami (2004) reported that fermentation significantly increase invitrorottein digestibility and decreased polyhenol and phytic acid content of fluted pumpkin seeds. The invitroprotein digestibility reported in this study revealed that as the increase in the soaking period increases from zero hr to 16 hrs there was improvement in the digestibility of akara and mom-mom while the polyphenols and phytic acid content decreased significantly $(\mathrm{p}<0.05)$.

\section{Conclusion}

Base on the results of this study, it is advisable to soak cowpea and maize that will be use for akara and moin-moin preparation for up to $8 \mathrm{hr}$ before dehaulling and grinding in other to improve the nutritional value of the "akara and moin-moin".

\section{REFERENCES}

[1] Achiriewhu, S.C. (1986). 5ome biochemical and nutritional changes during fermentation of fluted pumpkin (Telfaira occidentialis) Plant Foods Hum Nut 36: 97-106.

[2] Akingele and Akinylosotte (1991). 
[3] Akpakpunam, M.A (1985). Characteristics of mom-mom flour prepared from cowpea.mazie blends. Nigerian Food Journal 2(3): 207-208.

[4] Akusu, O.M and Kiin-Kabari, b.B (2012). Protein quality and sensory evaluation of mom-mom prepared from cowpea/maize flour blends. African Journal of Food Science 6(3): 47-51.

[5] AOAC (2006). Official method of analysis (18th ed.) Washington, D.C. Association of official analystical chemist.

[6] Barber, L.I, Ibiama E.A, Achinewhu S.C. (1989) Microorganisms associated with fermented fluted pumpkin seeds (Telfaira ocidentialis) lnt. Journal Food Science Technology 24: 189-193.

[7] Gatehouse and Boulker (1983).

[8] Giami, 5.Y (2004). Effect of fermentation on the seed proteins, nitrogenous constituents, anti nutrients and nutritional quality of fluted pumpkin (Telfaira occidentalis Hook) Food Chemistry, 88: 397-404.

[9] Giami, S.Y, Akusu, M.O and Jaja, I.R. (2003). Production, organoleptic assessment and nutritional properties of akara from cowpea/maize flour blends. Plant Foods for Human Nutrition. 58: 1-9.

[10] Liener, I.E (1976) "Legume toxins in relation to protein digestibility - a review". Journal of Food Science. 41:1076-1079.

[11] Liener, I.F (1980) "Miscellaneous toxic factors" In: Liener, I.E (Ed). Toxic constituents of plant food Stuffs. London: Academic press, pp 430-467.

[12] McWatters, K.H (1983) Compositional, physical and sensory characteristics of "akara" processed from cowpea paste and Nigerian cowpea flour. Cereal Chem. 60: 333-336.

[13] Monsor, M.A and Yusuf, H.K.M. (2002) "In-vitro protein digestibility of lathyrus pea (Lathyrus sativus), Lentil (Lens culinaris) and chickpea (Cicer arietinum)". International journal of Food Science and Technology 37(1): 97-99.

[14] Ngoddy, P.O. Enwere, N and Onuorah, V.I (1986) Cowpea flour performance in "akara" and "moin-moin" preparation. Tropical Science, 26, 101-119.

[15] Odum, P.K: Ademason, L.A, Moragne, A.L. Edwards, C.H (1981). A weaning food from locally grown grain in Nigeria. Formulation and organoleptic evaluation. Nutritional Reports International, 23: 1005-1019.

[16] Sanders, R.M, Connor, M.A, Booth, A.N, Bickoff, E.M and Kohler, G.O. (1973). Measurement of digestibility of alfalfa protein concentrates by in vitro and in vitro methods. Journal of Nutrition 103: 530-535.

[17] Taylor, and Taylor, J.R.N (2002). Alleviation of the adverse effect of cooking on sorghum protein digestibility through fermentation in traditional porridges. International Journal of Food Science and Technology 37: 129-137.

[18] Taylor, J and Taylor, J.R.N (2002), Alleviation of the adverse effect of cooking on sorghum protein digestibility through fermentation in traditional African porridges. International Journal of Food Science and Technology, 37: 129-137.

[19] Van Egmond, H.P and Speyers, G.J.A (1990) "Naturally occurring toxicants in foodstuffs, 2. Plant toxins. Food Laboratory News. 6: 18-25. Venderpoel.

[20] Wahun, T.A.T (1999). Applied 5tatistics for scientific studies. Aba Nigeria African Link Press.

[21] Wheeler, E.L and Ferrel, .E (1971). A method of phytic acid determination in wheat and wheat fractions. Cereal Chemistry, 48, 312-316.

[22] Wison, M.F and Blunden, C.A (1983). Changes in the level of polyphenols in three pea varieties during bud development. Journal of the Science of Food and Agriculture 34, 973-978. 